\title{
Toiminnan keskeytymisen ja toimintaan palaamisen multimodaaliset käytänteet englannin- ja suomenkielisessä vuorovaikutuksessa
}

\author{
Marika Helisten
}

\section{Väitöksenalkajaisesitelmä Oulun yliopistossa 2. marraskuuta 2018}

Väitöskirjani aiheena on tuttu arkielämän ilmiö, jota esiintyy lähestulkoon kaikessa ihmisten välisessä sosiaalisessa kanssakäymisessä ja josta usein puhutaan jokseenkin negatiiviseen sävyyn. Tarkastelen tutkimuksessani sitä, miten puheen ja toiminnan keskeytyksiä käsitellään vuorovaikutuksessa. Kyseessä on potentiaalisesti ongelmallinen ja jossain määrin arkaluontoinenkin asia: jo pienestä pitäen meille opetetaan, että toisen keskeyttäminen on epäkohteliasta ja tylyä. Keskeytysten koetaan häiritsevän meneillään olevaa keskustelua ja toimintaa tai hidastavan ja vaikeuttavan jonkin käsillä olevan tehtävän suorittamista. Kuitenkin arjen vuorovaikutustilanteissa keskeytyksiä tapahtuu usein. Yksi vuorovaikutukseen osallistuja alkaa puhua kesken keskustelukumppanin puheenvuoron; toinen keskeyttää meneillään olevan yhteisen toiminnan kiinnittämällä muiden huomion johonkin äkilliseen ja ennakoimattomaan tapahtumaan ympäristössä.

Keskeytyksiä tapahtuu usein tilanteissa, joissa on meneillään monenlaista toimintaa. Voimme esimerkiksi keskustella illallispöydän ääressä ja samalla valmistaa ruokaa ja tarjoilla sitä toisillemme, käyttää puhelimia tai tietokoneita ja paimentaa lapsia. Käytännössä emme useinkaan tee näitä eri asioita siistissä järjestyksessä, yksi asia kerrallaan ja peräkkäin, vaan eri toiminnot ja niiden vaiheet etenevät toistensa lomassa. Välillä voimme jakaa huomiomme useamman meneillään olevan toiminnan kesken samanaikaisesti, kun taas välillä meidän pitää valita, mikä on välittömämpää huomiota vaativaa ja mikä voi odottaa. Sitä, miten nämä eri toiminnot käytännössä järjestyvät ja etenevät, ei ole spontaanissa vuorovaikutuksessa ennalta käsikirjoitettu. Osallistujien teh- 
tävänä on neuvotella yhteistyössä, miten he jäsentävät toimintaansa, mikä on eri toimintojen välinen hierarkia ja miten ja milloin siirrytään toiminnosta tai sen vaiheesta toiseen.

Neuvottelu tutkimissani arkielämän tilanteissa ei kuitenkaan ole samalla tavalla eksplisiittistä ja etukäteen muotoiltua agendaa noudattavaa kuten vaikkapa neuvottelu työpaikan kokouksessa yhteisistä tavoitteista tai neuvottelu eduskunnan budjettiriihessä. Se on hienovaraista toimintaa, pieniä puheen ja kehollisen toiminnan keinoja, joita emme osallistujina välttämättä edes miellä tai tunnista neuvotteluksi. Eräänlaista arkielämän neuvottelua on myös se, miten keskeytyksiä käsitellään vuorovaikutuksessa: miten keskeyttävä puhe ja toiminta aloitetaan, miten se muuttaa osallistujien toimintaa ja miten keskeytyneeseen toimintaan myöhemmin palataan. Tutkimukseni perusteella keskeytykset eivät yleensä ole ongelma osallistujille itselleen vaan pikemminkin keino jäsentää meneillään olevaa toimintaa ja käsitellä yllättäviä tai ennakoimattomia tilanteita vuorovaikutuksessa. Osallistujilla on systemaattisia vuorovaikutuksen keinoja luovia näissä tilanteissa yhteisymmärryksessä ja yhteistyössä keskenään. Näitä keinoja pyrin väitöskirjassani kartoittamaan ja kuvaamaan.

Tutkimuksen aineisto koostuu videoiduista englannin- ja suomenkielisistä aidoista arkielämän vuorovaikutustilanteista. Suurin osa aineistosta on peräisin $\mathrm{Ou}$ lun yliopiston englantilaisen filologian oppiaineessa kerätystä Oulu Video Corpus -kokoelmasta, johon on kerätty aineistoa Suomessa, Englannissa, Yhdysvalloissa ja Australiassa. Lisäksi pieni osa suomenkielistä aineistoani on peräisin Keskusteluntutkimuksen arkistosta, joka on Helsingin yliopiston suomen kielen oppiaineen ylläpitämä korpus. Näistä kokoelmista käyttämäni aineisto käsittää yhteensä noin 33 tuntia, joista 18 tuntia on englanninkielistä ja noin 15 tuntia suomenkielistä vuorovaikutusta.

Tutkimusmenetelmänä käytän keskustelunanalyysia, jota käytetään yleisesti sosiaalisen vuorovaikutuksen tutkimuksessa muun muassa kielitieteen, sosiologian ja antropologian aloilla. Sen avulla voidaan tunnistaa ja kuvata vuorovaikutuksen perusmekanismeja, jotka jäsentävät ja ohjaavat ihmisten välistä sosiaalista kanssakäymistä ja joiden kautta osallistujat rakentavat ja saavuttavat yhteisymmärryksen erilaisissa vuorovaikutustilanteissa. Keskustelunanalyysi sai alkunsa 1960-luvulla Kaliforniassa, kun amerikkalainen sosiologi Harvey Sacks kollegoineen kehitti aivan uudenlaisen lähestymistavan yhteiskunnan jäsenten sosiaalisen elämän tutkimukseen. Heidän lähestymistapansa perustui nauhoitettujen, aitojen vuorovaikutustilanteiden empiiriseen tarkasteluun, jossa lähtökohtana ei ollut jokin tutkijan ennalta määrittelemä teoria vaan itse aineisto ja siitä nousevat ilmiöt. Ääninauhoitteet mahdollistivat puheaineiston toistuvan ja yksityiskohtaisen tarkastelun ja sen myötä sellaisten hienovaraisten vuorovaikutuskäytänteiden tunnistamisen, joita olisi ollut muilla menetelmillä vaikea havaita. Sacks kumppaneineen pystyi empiirisesti osoittamaan, että toisin kuin siihenastisessa sosiologisessa tutkimuksessa oli oletettu, vuorovaikutus ei ollutkaan sattumanvaraista, epäloogista ja kaoottista vaan hyvin pitkälle järjestynyttä ja jäsentynyttä toimintaa, jota ohjasivat tietyt lainalaisuudet ja säännöt (esim. Sacks, Schegloff \& Jefferson 1974). Tarkastelun keskiössä olivat yhteiskunnan jäsenten jokapäiväisen, arkisen vuorovaikutuksen käytänteet, joiden avulla he rakentavat sosiaali- 
sia toimintoja ja saavuttavat sosiaalisia päämääriään. Keskustelunanalyyttisessa tutkimuksessa sosiaalisen järjestyksen nähdään rakentuvan paikallisesti, ihmisten välisen, vuoro vuorolta ja hetki hetkeltä etenevän vuorovaikutuksen kautta. Keskusteluntutkijan näkökulmasta se, minkä osallistujat omalla toiminnallaan osoittavat olevan heille merkityksellistä, on merkityksellistä myös tutkijalle.

Väitöskirjani pyrkiikin omalta osaltaan valottamaan erästä tällaista osallistujille merkityksellistä vuorovaikutuksen ilmiötä. Se koostuu kolmesta osatutkimuksesta, jotka tarkastelevat kielen, toiminnan ja kehonkäytänteiden välisiä kompleksisia suhteita sekä niiden yhteispeliä keskeytysten käsittelyssä eri näkökulmista. Erityisenä tarkastelun kohteena ovat 1) keskeyttävän toiminnan aloitukset eli sellaiset vuorovaikutuksen hetket, jolloin meneillään oleva toiminta keskeytetään toisen vuoksi, ja 2) paluut keskeytyneeseen toimintaan sen jälkeen, kun väliin tullut, keskeyttävä toiminta on saatettu päätökseen. Työssäni kuvaan, kuinka nämä siirtymät tuotetaan multimodaalisesti eli puheen piirteitä ja kehollisia resursseja hyödyntäen ja yhteistyössä osallistujien kesken.

Etenkin vuosituhannen vaihteen jälkeen, pitkälti videoteknologian kehittymisen ja yleistymisen myötä, sosiaalisen vuorovaikutuksen tutkimuksessa painopiste on alkanut yhä enemmän siirtyä äänitallennetun puheen tutkimuksesta kokonaisvaltaisempaan suuntaan siten, että puheen lisäksi myös osallistujien kehollinen toiminta ja se tila ja ympäristö, jossa vuorovaikutus tapahtuu, nähdään merkityksellisinä vuorovaikutuksen resursseina. Tästä huolimatta on olemassa toistaiseksi verrattain vähän tutkimusta, joka pyrkii kuvaamaan systemaattisesti näiden eri resurssien välisiä kompleksisia suhteita ja yhteispeliä ihmisten välisessä vuorovaikutuksessa. Pyrinkin väitöskirjassani vastaamaan tähän tutkimusvajeeseen tarkastelemalla puheen ja toiminnan keskeytyksiä kokonaisvaltaisesta näkökulmasta.

Vastaan väitöskirjassani seuraaviin tutkimuskysymyksiin: 1) Millä tavoin toiminnan keskeyttäminen ja siihen paluu ovat tunnistettavia ja merkityksellisiä toimintoja osallistujille itselleen? Esimerkiksi miten osallistujat neuvottelevat toimintojen välisen hierarkian ja priorisoivat toimintojaan tilanteissa, joissa on meneillään useampi, samanaikainen toimintalinja? 2) Millaisia kielellisiä, prosodisia ja kehollisia käytänteitä aineistosta on löydettävissä, ja mikä on kielellisten ja kehollisten resurssien, kuten eleiden, katseen, ilmeiden ja kehonliikkeiden, välinen suhde ja niiden rooli toiminnan keskeytyksessä ja siihen paluussa?

Seuraavaksi esittelen pääpiirteissään väitöskirjani tulokset. Kaikki kolme osatutkimusta osoittavat, kuinka tiettyjen, aineistossa toistuvasti esiintyvien kielen keinojen lisäksi osallistujat hyödyntävät aiemmin tiedettyä enemmän hienovaraisia kehollisia resursseja keskeytysten käsittelyssä. Nämä resurssit muodostavat systemaattisia multimodaalisia käytänteitä, jotka esiintyvät johdonmukaisesti sekä englannin- että suomenkielisessä vuorovaikutuksessa eivätkä siis tutkimuksen perusteella näytä olevan sidoksissa pelkästään yhteen kieleen ja kulttuuriin.

Osatutkimus II (Helisten tulossa 2019) käsittelee keskeyttävän toiminnan aloituskohtia englannin- ja suomenkielisessä vuorovaikutuksessa. Näissä tilanteissa yksi osallistuja havaitsee jotain yllättävää tai ennakoimatonta osallistujien konkreettisessa toimintaympäristössä, ja tämän hän tuo myös toisten tietoon keskeyttäen näin juuri 
meneillään olevan yhteisen toiminnan. Artikkeli problematisoi keskeyttämisen käsitteen vuorovaikutuksessa osoittamalla, että tutkitussa aineistossa keskeyttäminen on itse asiassa tyypillisesti hyvin hienovaraista toimintaa. Siinä keskeyttäjä ajoittaa vuoronsa tarkasti ja mahdollisimman vähän meneillään olevaa toimintaa häiritsevästi, esimerkiksi käyttämällä hiljaista ääntä tai osoittavaa elettä.

Alla esitetyssä aineistokatkelmassa (1-a) on esimerkki tällaisesta hienovaraisesta keskeytyksestä. Katkelma on analysoitu tarkemmin väitöskirjani yhteenveto-osuudessa. Kuvassa 1A (s. 5) vasemmalla istuva Hanna suuntaa heti katkelman alussa (rivi o1) huomionsa yhteen osallistujia kuvaavista kameroista. Kuten katkelmasta käy ilmi hieman myöhemmin, hän havaitsee kameraan liittyvän potentiaalisen ongelman (rivit 10 ja 11). Hän ei kuitenkaan tuo tätä välittömästi ilmi vaan seuraa tarkasti keskellä istuvan Markuksen meneillään olevaa kerrontavuoroa (rivit 01-06) sekä Markuksen ja oikealla istuvan Elinan kehollista toimintaa ja odottaa sopivaa hetkeä havaintonsa esiintuomiseksi. ${ }^{1}$

(1-a) Oulu Corpus, $006(<\mathrm{T}: 00: 01: 19>)$

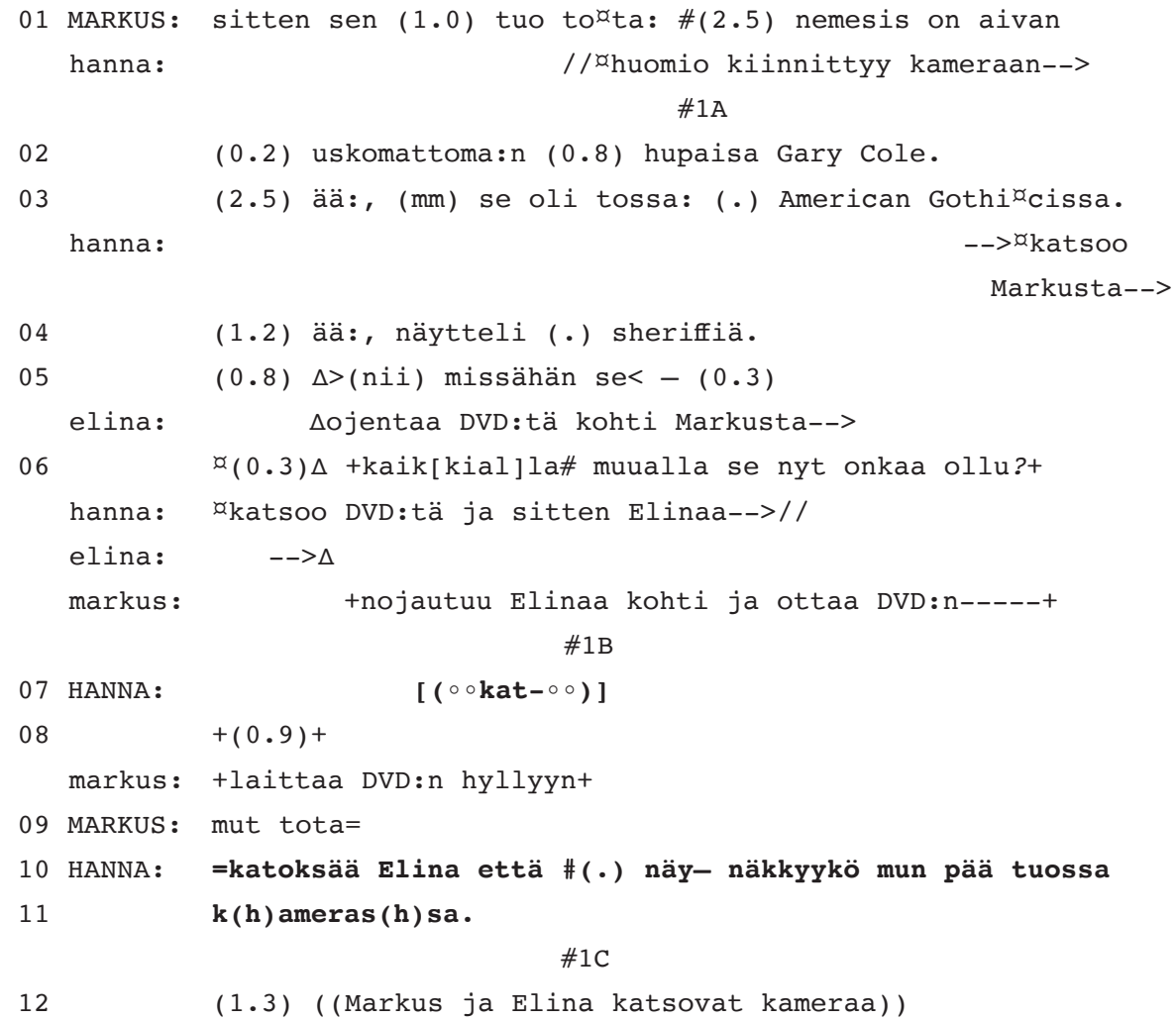

1. Osallistujien kehollisen toiminnan litterointi perustuu pääasiassa Lorenza Mondadan kehittämään tyyliin (ks. tekstin lopussa oleva tarkempi kuvaus). Kohdissa, jotka eivät ole analyyttisen tarkkailun keskiössä, osallistujien kehollinen toiminta on kuvattu lyhyesti kaksoissulkeiden sisällä, eikä sitä ole synkronoitu puheen kanssa samalla tarkkuudella kuin Mondadan tyylissä. 
13 MARKUS: ('no luulis kyllä॰), (1.9) ai nii se on tuo kamera.

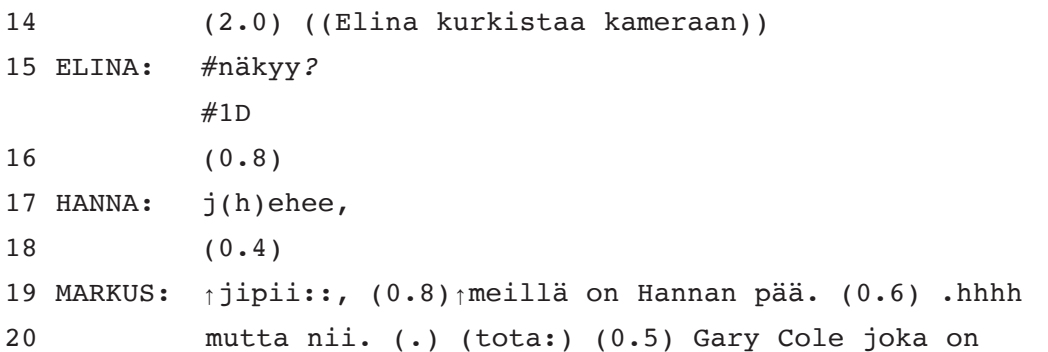

Markuksen kerronta keskeytyy hetkeksi, kun Elina ojentaa hänelle DVD-elokuvan kannen (rivit 05 ja 06; kuva 1B). Tämän kehollisen toiminnon aikana Hanna yrittää ottaa vuoron (rivi 07), mutta Markuksen jatkaessa kerrontaansa (rivi o6) Hanna jättää oman vuoronaloituksensa kesken ja jää odottamaan otollisempaa hetkeä. Pian Markuksen kerronnassa seuraa toinen, pidempi tauko (rivi o8), jonka aikana hän asettaa Elinan ojentaman DVD:n oikealla puolellaan olevaan hyllyyn. Tämä siirtymän mahdollistava paikka tarjoaa Hannalle uuden mahdollisuuden ottaa havaitsemansa ongelma puheeksi, minkä hän lopulta tekeekin rivillä 10 - vaikka Markus ehtiikin aloittaa uuden vuoron hieman ennen häntä (rivi 09).

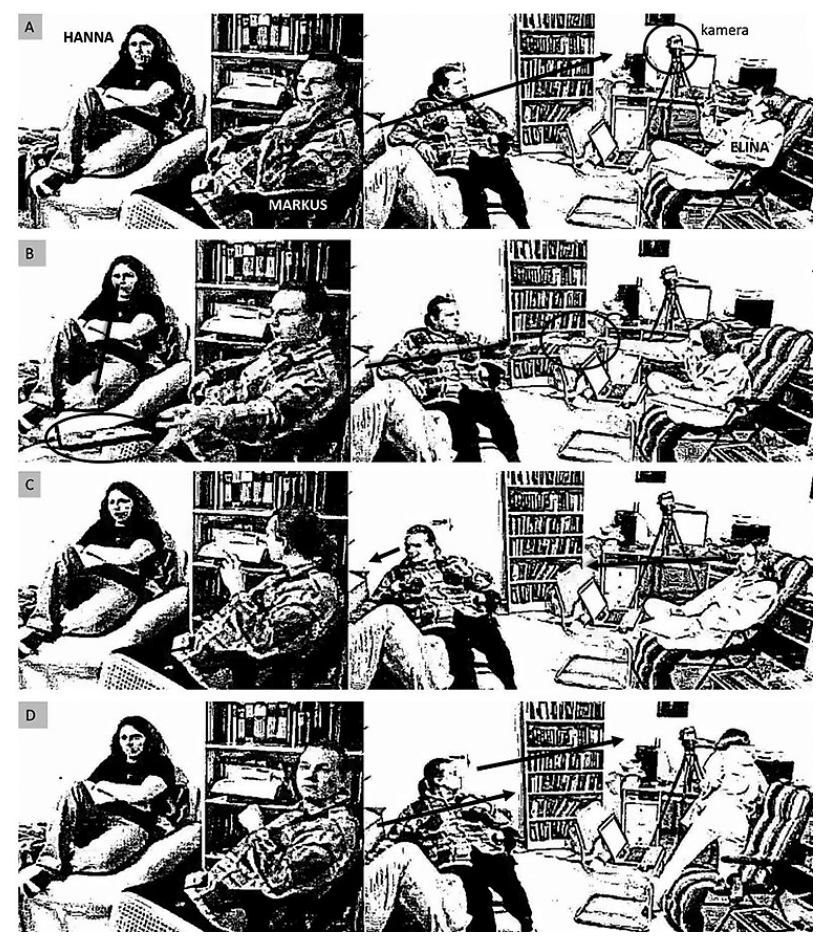

Kuva 1.

Hanna keskeyttää meneillään olevan kerronnan kameraan liittyvän ongelman vuoksi. 
Hannan väliin tuleva vuoro on tarkasti ajoitettu. Yhtäältä hän käsittelee huomiotaan kiireellisenä pyrkien ottamaan vuoron mahdollisimman pian ongelman havaittuaan. Toisaalta hän huomioi meneillään olevan toiminnan ja vuorovaikutuksen kulun ja pyrkii välttämään suoranaista keskeyttämistä. Toiset osallistujat eivät torju tai sanktioi Hannan aloittamaa, väliintulevaa toimintajaksoa vaan osoittavat kielellisten responssiensa ja kehon orientaatioidensa kautta käsittelevänsä sitä legitiiminä toimintana, johon he myös omalla toiminnallaan osallistuvat (rivit 13-15 ja 19; kuvat $1 \mathrm{C}$ ja $1 \mathrm{D}$ ). Kun havaittu ongelma on yhdessä ratkaistu, keskeytynyt kerronta jatkuu (rivi 20).

Osatutkimukset I (Helisten 2017) ja III (Sutinen 2014) puolestaan keskittyvät toimintaan paluuseen hieman eri toimintakonteksteissa. Osatutkimus I tarkastelee paluukäytänteitä pidemmissä tarinankerrontavuoroissa, joissa pääsääntöisesti yksi puhuja on äänessä ja muut ovat kerronnan vastaanottajina. Osatutkimus III keskittyy paluihin monitoimintatilanteissa, joissa osallistujat koordinoivat toimintaansa useamman samanaikaisen tai yhtä aikaa huomiota vaativan toiminnan välillä. Molemmat osatutkimukset osoittavat, kuinka osallistujien kollektiivinen siirtyminen takaisin keskeytyneeseen toimintaan ei tapahdu automaattisesti vaan vaatii osallistujien välistä yhteistyötä ja hienovaraista neuvottelua. Tässä neuvottelussa ovat puheen lisäksi tärkeässä roolissa etenkin kehollinen toiminta sekä osallistujien toiminnalle merkitykselliset, käsillä olevat konkreettisen ympäristön esineet ja piirteet. Tutkimissani monitoimintatilanteissa siirtyminen toiminnasta toiseen on vaiheittainen prosessi, joka käynnistyy jo siinä vaiheessa, kun keskeyttävä toiminta on vielä käynnissä. Tämä vaiheittain tapahtuva siirtyminen tarjoaa osallistujille oivan vuorovaikutuksen resurssin liikkua joustavasti eri toimintojen välillä tilanteissa, joissa haasteena on monen samanaikaisesti huomiota vaativan asian hallitseminen sekä ennakoimattomiin tapahtumiin reagoiminen jo meneillään olevan toiminnan lomassa.

Tulosten perusteella näyttääkin siltä, että kielellä ja keholla on omat erityiset tehtävänsä sekä keskeyttävän toiminnan aloituksissa että toimintaan paluissa: kielen avulla nämä siirtymät tuotetaan ja merkitään eksplisiittisesti tavoilla, jotka ovat osallistujille tunnistettavia. Aiemmin esittelemässäni aineistoesimerkissä, joka on esitetty alla uudelleen (katkelma 1-b), Markus palaa keskeytyneeseen kerrontaansa rivillä 20.

(1-b) Oulu Corpus, 006 ( $<$ T:00:01:42>)

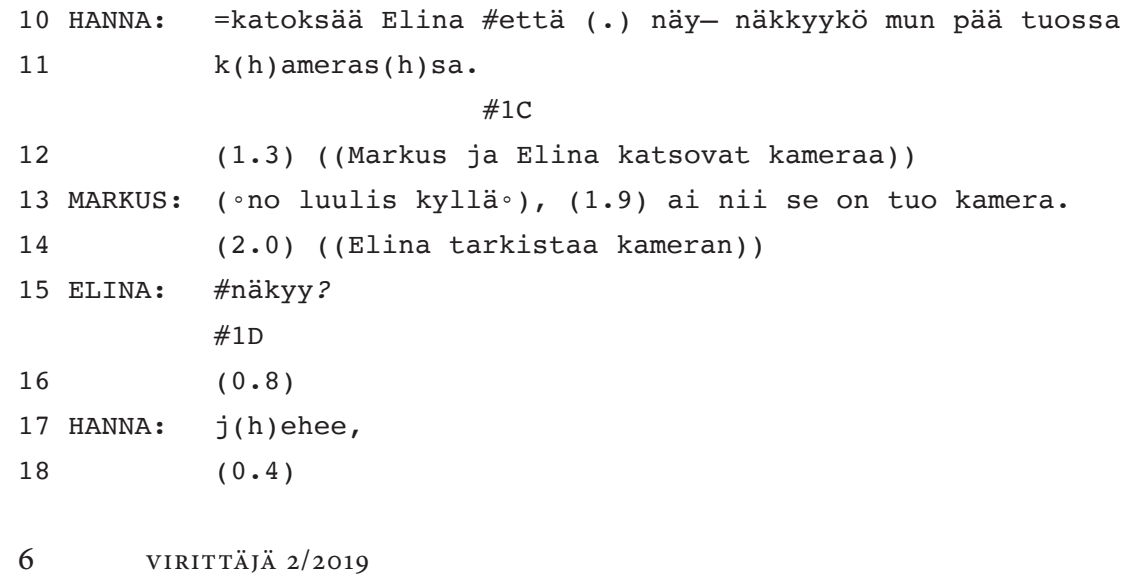




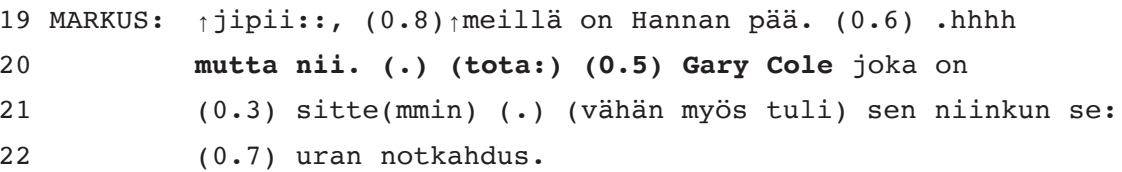

Ensin Markus tuottaa suomenkielisessä aineistossa tyypillisesti esiintyvän siirtymän merkitsimen mutta nii, jonka jälkeen hän toistaa näyttelijän nimen Gary Cole, joka oli hänen kerrontavuoronsa aiheena ennen väliintullutta keskeytystä. Vasta tämän jälkeen hän jatkaa kerrontaansa varsinaisesti eteenpäin (rivit 21 ja 22).

Kehon resurssit toimivat näissä siirtymissä hienovaraisemmin. Katseen suunnalla, eleillä ja kehon orientaatioilla voidaan muun muassa valmistella ja ennakoida tulevaa siirtymää ja neuvotella sopivasta siirtymän hetkestä. Seuraavassa, englanninkielisestä aineistosta poimimassani katkelmassa (2) on esimerkki tällaisesta vaiheittaisesta siirtymästä. Kuvassa 2A (s. 9) vasemmalla istuva Lynne ja oikealla istuva Rebecca ovat työskennellet yhdessä läppärin äärellä. Tämä toiminta on kuitenkin keskeytynyt jo pari minuuttia ennen katkelmaa, koska Lynne on alkanut kertoa tarinaa taannoisesta, ystävien kanssa viettämästään illasta, johon liittyi myös pitkällinen jonotus taksitolpalla. Allaolevassa katkelmassa riveillä 01-14 tarina viedään vaiheittain päätökseensä. Kolmas osallistuja, Gwyneth, ei näy kuvassa tällä hetkellä koska on hieman sivummalla valmistamassa päivällistä, mutta hänkin osallistuu keskusteluun.

(2) Oulu Corpus: 007 (tape $1<$ T:00:07:05>)

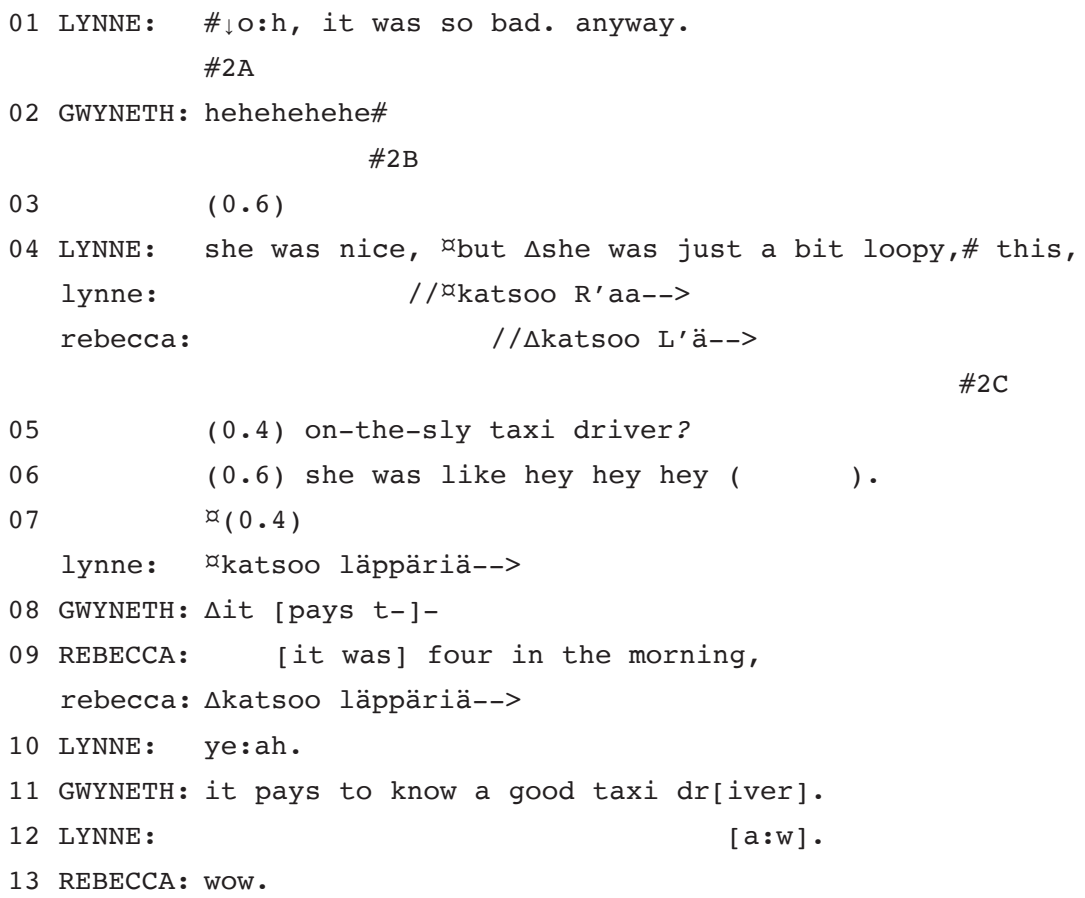




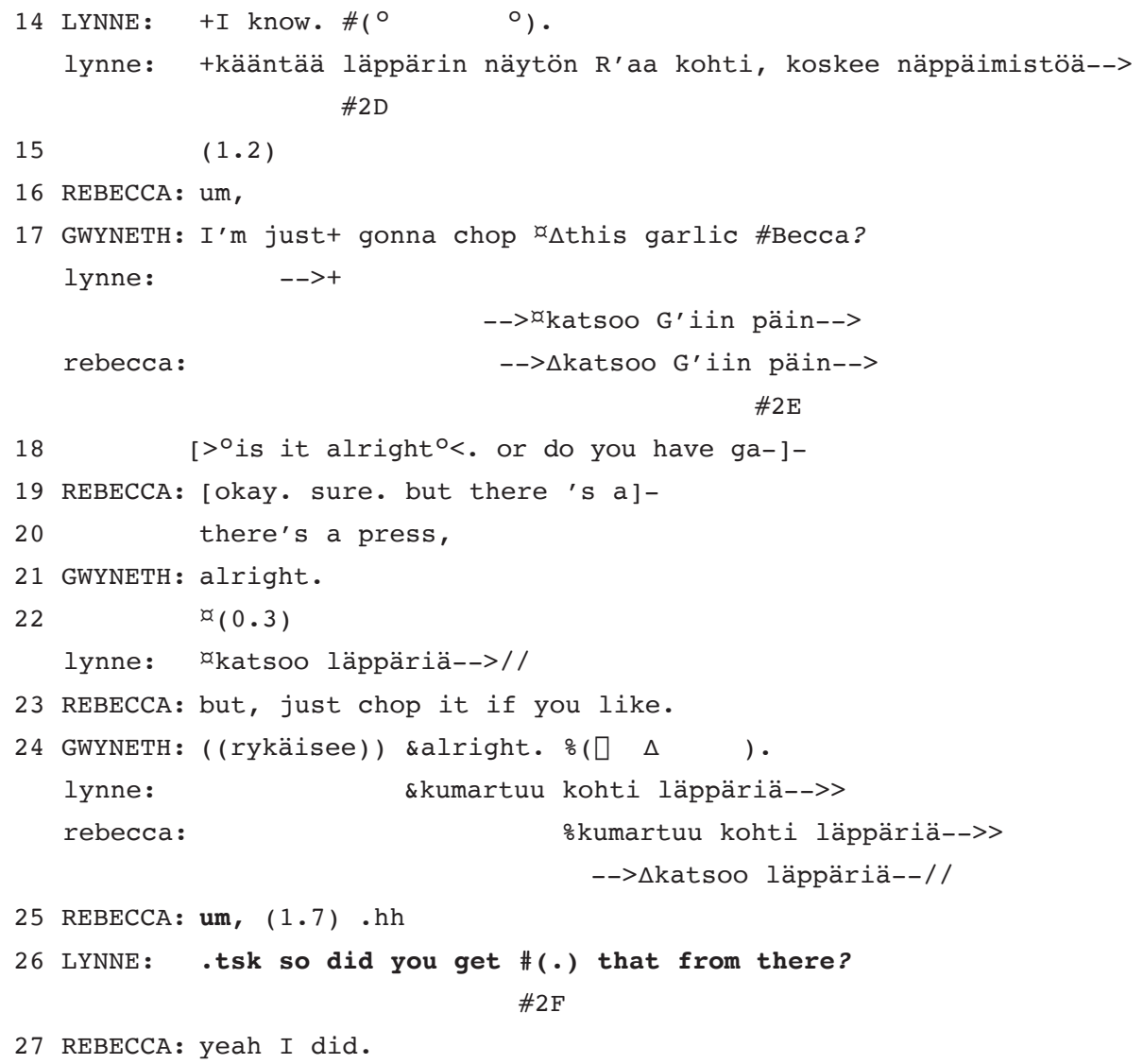

Tämän katkelman tarkempi analyysi löytyy osatutkimuksesta III. Katkelmassa kuitenkin näemme, kuinka tarinankerronnan pättäminen ja keskeytyneeseen toimintaan palaaminen ei ole aina niin yksinkertaista kuin voisi kuvitella. Katkelman alussa näyttää siltä, että tarina on jo tulossa päätökseensä: Lynne tuottaa kerrontavuoroille tyypillisen, tarinaa arvioivan loppulausuman oh, it was so bad (rivi o1) ja orientoituu hyvin selkeästi kehollaan kohti läppäriä, kuten kuvassa 2A näkyy. Rebecca seuraa perässä ja kumartuu hänkin kohti läppäriä (kuva $2 \mathrm{~B}$ ). Näin osallistujat osoittavat toisilleen kehojensa suuntautumisella hienovaraisesti omaa valmiuttaan palata takaisin läppärillä työskentelyyn ilman eksplisiittistä sanoittamisen tarvetta.

Spontaanissa vuorovaikutuksessa tilanteet voivat kuitenkin muuttua hetkessä kuten tässäkin tapauksessa. Ennen kuin Lynne ja Rebecca lopulta palaavat takaisin keskeytyneeseen työskentelyynsä, väliin tulee vielä kaksi paluuta lykkäävää toimintajaksoa. Ensimmäinen jakso käynnistyy rivillä o4, kun Lynne päättääkin vielä yllättäen jatkaa tarinaansa, jolloin osallistujat myös kehollisesti vetäytyvät paluusta ja asettuvat uudelleen keholliseen tarinankerrontamuodostelmaan (kuva $2 \mathrm{C}$ ). Toisessa tapauksessa Lynnen ja Rebeccan paluuaikeet, jotka näkyvät etenkin heidän kehollisessa toiminnassaan riveillä 07 , 09 ja 14 ja kuvassa $2 \mathrm{D}$, keskeyttää vuorovaikutuksen kolmas, kuvan ulkopuolella oleva osallistuja eli Gwyneth. Hän tuottaa rivillä 17 vuoron, joka suuntaa kaik- 


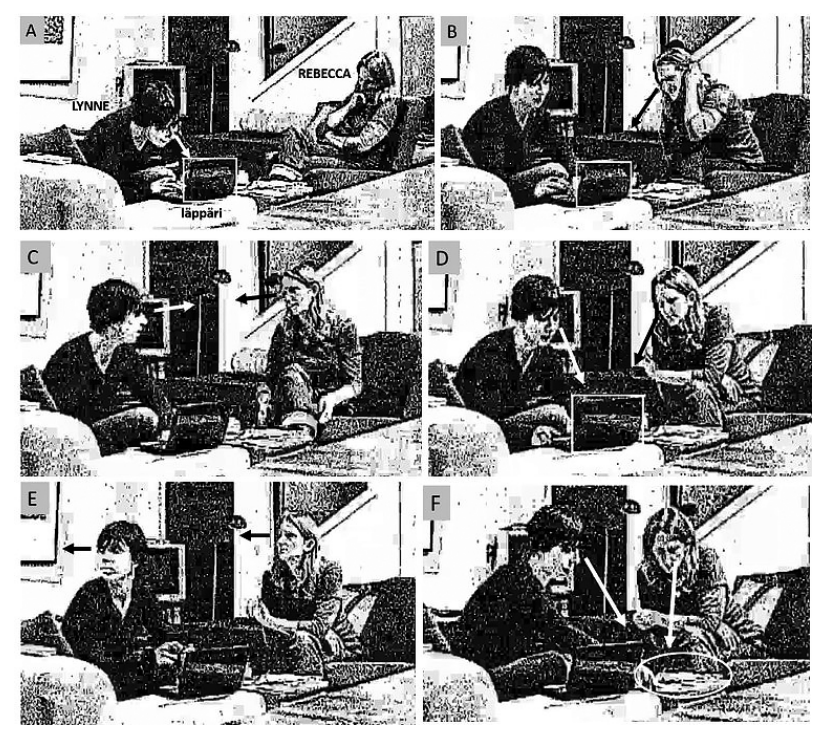

Kuva 2.

Lynne ja Rebecca neuvottelevat multimodaalisesti paluusta keskeytyneeseen työskentelyynsä.

kien huomion ruoanlaittoon liittyviin asioihin (kuva $2 \mathrm{E}$ ) ja näin lykkää edelleen keskeytyneeseen toimintaan paluuta.

Nämä keskeytykset eivät kuitenkaan aiheuta vuorovaikutusta häiritsevää katkosta tai konfliktitilannetta osallistujien kesken. Vaiheittain tapahtuvat siirtymät antavat osallistujille mahdollisuuden tunnustella ja kuulostella, mikä on heidän yhteinen ymmärryksensä meneillään olevasta toiminnasta ilman, että asiasta täytyisi eksplisiittisesti neuvotella. Ne mahdollistavat myös joustavan reagoinnin yllättäviin tai ennakoimattomiin tapahtumiin spontaanissa vuorovaikutuksessa. Etenkin kehollisilla resursseilla voidaan ilmaista hienovaraisesti joko valmiutta tai valmistautumattomuutta palata takaisin keskeytyneeseen toimintaan ja näin saavuttaa yhteisymmärrys siitä hetkestä, jolloin siirtymä lopulta tapahtuu. Ylläolevassa katkelmassa siirtymä tapahtuu vasta riveillä 25 ja 26 , jolloin Lynne ja Rebecca tuottavat paluuta merkitsevät vuorot sekä suuntautuvat kehollisesti keskeytyneeseen toimintaansa muun muassa katseella sekä osoittamalla ja koskettamalla läppäriä ja muita pöydällä olevia esineitä, jotka ovat merkityksellisiä toiminnalle, johon he ovat palaamassa (kuva $2 \mathrm{~F}$ ). Väitöskirjani tulokset siis osoittavat, että puheen lisäksi jaettu kehollinen läsnäolo ja viestintä sekä toimintaympäristön konkreettisten piirteiden ja esineiden hyödyntäminen mahdollistavat yhdessä kitkattoman ja sujuvan vuorovaikutuksen kulun tilanteissa, joissa osallistujat jäsentävät toimintaansa useamman samanaikaisesti huomiota vaativan toiminnan kesken. Näissä tilanteissa toiminnan keskeyttämisen ja siihen palaamisen hienovaraiset, multimodaaliset neuvottelukäytänteet osoittavat myös yleisemmällä tasolla, kuinka monimutkainen ilmiö ihmisten välinen vuorovaikutus onkaan ja kuinka monitasoista kompetenssia se osallistujilta vaatii.

Miksi sosiaalisen vuorovaikutuksen ilmiöitä kuten toiminnan keskeytystä ja siihen paluuta sitten kannattaa ylipäätään tutkia? Vuorovaikutus on kaiken inhimil- 
lisen toiminnan perusta. Ihmiset tekevät ja saavuttavat asioita yhdessä ja olemalla vuorovaikutuksessa keskenään, niin jokapäiväisissä arkisissa tilanteissa ystävien ja perheenjäsenten kesken kuin virallisemmissa yhteyksissä, kuten työpaikoilla, virastoissa, terveydenhuollossa, opetuksessa ja politiikassa. Kaikilla näillä yhteiskunnan alueilla tehdään päätöksiä ja saavutetaan tavoitteita ihmisten välisen vuorovaikutuksen avulla ja sen seurauksena. Tästä huolimatta on vielä paljon, mitä emme tiedä vuorovaikutuksen perusmekanismeista, kielen, kehollisuuden ja ympäröivän maailman välisistä suhteista ja keskinäisestä yhteydestä sekä siitä, miten nämä rakentavat sosiaalista vuorovaikutusta ja toimintaa. Pienet ilmiöt, kuten keskeytysten käsittely vuorovaikutuksessa, eivät ehkä itsessään ole maata järisyttäviä tai yhteiskunnan tasolla merkittäviä, mutta ne tekevät paikallisella tasolla näkyväksi, miten ihmiset hahmottavat ja jäsentävät toimintaansa ja rakentavat yhteisymmärrystä ja sosiaalista järjestystä arjessaan.

\section{Kehollisen toiminnan litterointiperiaatteet}

(Perustuvat Lorenza Mondadan kehittämään litterointityyliin, esim. 2014.)

$\ltimes \quad \propto \quad$ Kunkin osallistujan kehollisen toiminnon kuvaus on rajattu kahden identtisen symbolin väliin

$+\quad+\quad$ ja synkronoitu samanaikaisen puheen kanssa.

an-> Kuvattu toiminto jatkuu seuraavilla riveillä

--> $\quad$ ja päättyy, kun sama symboli tulee vastaan.

œ--> Kuvattu toiminto jatkuu vielä katkelman päättymisen jälkeen.

// Kohta, jossa tietyn kehollisen toiminnon tarkastelu alkaa/päättyy.

markus Osallistuja, jonka kehollista toimintoa kuvataan, on merkitty pienillä kirjaimilla.

\# $\quad$ Kuva. Se tarkka hetki, jolloin kuvakaappaus on otettu.

\section{Lähteet}

Helisten, Marika 2017: Resumptions as multimodal achievements in conversational (story)tellings. - Journal of Pragmatics 112 s. 1-19. DOI: https://doi.org/10.1016/j.pragma.2017.01.014

_- (tulossa 2019): Disjunctively positioned problem-noticings in managing multiactivity. - Research on Language and Social Interaction.

MondadA, Lorenza 2014: The temporal orders of multiactivity: Operting and demonstrating in the surgical theatre. - Pentti Haddington, Tiina Keisanen, Lorenza Mondada \& Maurice Nevile (toim.), Multiactivity in social interaction. Beyond multitasking s. 33-75. Amsterdam: John Benjamins Publishing Company. DOI: https://doi.org/10.1075/ Z.187.02mon

Sacks, Harvey - Schegloff, Emanuel A. - Jefferson, Gail 1974: A simplest system- 
atics for the organization of turn-taking for conversation. - Language 50 s. 696-735. DOI: https://doi.org/10.2307/412243

Sutinen, MARIKa 2014: Negotiating favourable conditions for resuming suspended activities. - Pentti Haddington, Tiina Keisanen, Lorenza Mondada \& Maurice Nevile (toim.), Multiactivity in social interaction. Beyond multitasking s. 137-165). Amsterdam: John Benjamins Publishing Company.

Kirjoittajan yhteystiedot:

etunimi.sukunimi@oulu.fi 